\title{
Mobile Learning Design for Sight Reading
}

\author{
Maria Theresia Lintang Larasati*, Yudi Sukmayadi \\ Pascasarjana \\ Universitas Pendidikan Indonesia \\ Bandung, Indonesia \\ *mthlintang@gmail.com, yudi.sukmayadi@upi.edu
}

\begin{abstract}
Multimedia is developing in education, one of which uses mobile learning (m-learning) to expand learning in the classroom into everyday's life. This study aims to apply sight reading learning by using Musescore that can be accessed on smartphones. The target of this research is music students This study uses a developmental research method. Data was collected through visual analysis, literature study, and interviews then selecting and designing m-learning. The material is taken from the book Solfège des solfèges by Adolphe Danhauser which will be transcribed into Musescore to access with a smartphone. This application expected to train and help students in sight reading both in the classroom and in everyday's life.
\end{abstract}

\section{Keywords-m-learning, sight-reading, musescore}

\section{INTRODUCTION}

Nowadays, multimedia is important in our lives. Almost all fields use multimedia to carry out their activities. Multimedia describes a number of diverse technologies that combine visual and audio [1], for example, DVDs, televisions, music players, sound recorders, PowerPoint, and others. Multimedia helps students to increase their creativity, encourages them to explore, and enables them to achieve learning goals [2]. This also cannot be separated from how teachers integrate their teaching with the use of multimedia. One of the media that is very often used is a smartphone. According to statista.com, smartphone users in Indonesia reached 81.87 million. In addition to practical, smart phones also have many uses one of them is as a learning medium or commonly known as mobile learning (m-learning). Most of the application providers (apps store) such as the Play Store, Apple Store, Microsoft Store, and others provide a variety of music learning application that can be downloaded for free or for purchase. Several interesting studies show that learning using smartphone media makes it easier for students to learn flexibly, improve their abilities, and get new ideas [3].

Music educators have many technological resources available now. Access to the internet become easier that made contribution in a way of learning. It ensures a good success in the involvement of students in assigned task. Group work and individual activities become collaborative and autonomous, learning by teahing other and making decision to achieve a goal or selecting the most important materials. The creation of music promotes a real and comprehensive learning and reaching the four levels of knowledge: knowing, doing, being and acting. The Musical Perception and Expression classes are based on the experience of creating teaching musical activities for early childhood education [4]. In terms of music, mlearning help to expand classroom learning into everyday life. Thus, it can facilitate their learning outside of school such as composing, listening to various repertoires, practicing aural skills and recording their own performances. It shows that, $\mathrm{m}$ learning is also effectively used as a learning media in groups or independently.

The diversity of multimedia provide teacher and students to be more focused on develped the aural experiences as a musicianship for composition, improvisation and perfomance. Musescore as a WYSIWYG (What You See Is What You Get) application [5] offer way for developing aural skills of reading notation and playing instruments. Musescore is a professional score-writer made available for everyone. Program can be installed on as many devices inside and outside the classroom as students and teachers need. Free software programmes can contribute remarkably towards music learning witth ICT. Thus, this program rated highly the fact that the programmes have a simple interface, user-friendly and progressive [6] with possibilities for m-learning because of its open-source and mobility.

In order to developed the aural skills, student could learn sight-reading or primavista learning. Sight-reading increases musical literacy [7], develops aural skills [8], and increases self-confidence. This study would describe how m-learning can be a support in learning sight reading. The purpose of this study was to design a multimedia form of m-learning to be applied to sight reading learning.

\section{LITERATURE REVIEW}

Wai-Chung Ho examined the perceptions of music students in the use of multimedia at the graduate level in Hong Kong higher education. This study brings together research problems and real problems in the use of multimedia technology at the postgraduate level of music education to the challenges posed by the use of multimedia technology as a teaching and learning media for music. The results show that music students are confident in their ability to use multimedia technology but some disbelieve about introduction of multimedia technology 
into the curriculum will improve the quality of their education because students' motivation to learn depends on subject interest. The incorporation of technology must always be relevant to individual capabilities [9].

S.C. Ng, A.K. Lui, W.S. Lo (2013) designed an interactive learning using m-learning. The material presented is divided into three: basic music theory, games and how to play musical instruments. This application helps students explore music effectively and can see their learning process [10].

Adi Purwanto, Ida Widaningrum, Khoiru Nur Fitri developed the Musicroid application as an Android-based learning media for music which contains history of music, chords, quizzes and this application is integrated with Youtube Thus, students can access several other available learning videos on Youtube [11]

\section{METHODS}

This study uses developmental research method. Development research is defined as a systematic study in designing, developing, evaluating learning programs, processes and products. The data was collected through visual analysis, literature study, and interviews (individually or in groups) which would be analyzed. The next stage was to choose the material that would be used as sight-reading teaching materials then start designing with transcribed the scores, made the modules and wrote documentations. The target of this research is music students. This paper focuses on the presentation of multimedia design.

\section{DISCUSSION}

\section{A. Sight Reding}

Sight-reading, is defined as the ability to read and sing from a notation without listening to it first or what is commonly known as primavista. Sight-reading is one important measure to practice independence in music. Sight-reading is a complex process involving at least two different skills: reading skills and mechanical skills [12]. From a cognitive perspective, reading music requires multiple simultaneous processes including coding of visual information, motor responses and visual-motor integration [13]. Some of the benefits of sight-reading:

- Music literacy: sight-reading teaches how to understand the entire structure of music, including phrases, rhythm, and dynamics.

- Improve aural skills: sight-reading is like listen to music and read it. Singers with good sight-reading skills have the ability to hear and interpret what they have read. Develop an understanding of the interval, change the tonality and intonation is an important aspect of singing and can be improved with practice sight-reading ability

- Boosts self-confidence: practicing sight-reading also trains the courage to take risks. It cannot be denied that in the process you will find several errors in reading musical notation. Practicing sight-reading can be beneficial in increasing self-confidence.

\section{B. Mobile Learning}

Mobile learning is learning that utilizes technology and mobile devices such as laptops, smartphones, MP3 players, tablets, pocket computers. M-learning is a learning model that utilizes ICT. M-learning provides learning material that can be accessed by students at any time and is given an interesting visualization of material [14]. The use of m-learning helps to learn independently regardless of time and place [15]. Flexibility is the most visible thing in m-learning based learning because students can access material wherever they are. The use of m-learning technology in education is a technology that is needed to provide the main objective in distance education. M-learning offers learning options and data access for students who do not have sufficient time and space.

There are three main functions of using m-learning, which are functions of supplement, complement, and substitution. Supplement means that students are free to use mobile devices as learning media. The complement which means that the device can be used as an evaluation tool, providing enrichment, strengthening and can be used to repeat the learning that has been done. Meanwhile, the substitution means that students can be given the freedom to choose the learning model used, whether conventional learning models, technology-based learning models, or mixed models, namely the combination of conventional and technological models [16]. There are several benefits of m-learning, including [17]:

- M-learning helps in recignizing technologies that is useful in everyday life;

- It helps to apply new knowledge or abilities;

- Make it possible to use more media whenever possible;

- Provide access to experts;

- Build a community to practice.

\section{Musescore}

MuseScore is an easy-to-use, free license and professional music notation software package that runs on Windows, Linux and Mac. Its primary purpose is to create high-quality, digitally engraved musical scores. The free software license means it can be installed on as many computers as you need, and users can also be given copies of software to use at home. MuseScore meet all the necessities for an expert music notation software package for teachers and students at education establishments of all levels because it has easy-to-use interface, support for unlimited instruments, import and export of multiple formats. According to musescore.org [18], MuseScore is beneficial for teacher and students. It forms an ideal teaching platform for developing music literacy skills and making compositions. Student can increase their knowledge about this programme by self-instruction and practicing to produce the 
scores. It is also a great choice for teacher making materials for teaching and worksheets.

Many freely available thirdparty plugins have since been created to extend MuseScore's functionality. Forums exist that enable users to voice concerns or find help, and these forums are active and easy to navigate. By registering on the MuseScore website, one can log in and publicly or privately save, share or find existing MuseScore files made available by users under various licenses [19].

\section{Multimedia Design}

Currently, learning sight-reading in solfeggio uses a textbook with a piano. The current situation makes students studying online. Some students have difficulty to learn Primavista because of the lack of media to help learning at home. The media to be used combines visual and audio. It will help users read the notation because it is equipped with piano accompaniment. Tracks containing notations will run independently when the user presses the play button. It also enhance their reading speed. The tempo can be changed according to ability. The material used is the Solfège des solfèges by Adolphe Danhauser. The material chosen was the basic material for vocal sight-reading. Each material was equipped with an explanation. The notation in the book was transcribed to the MuseScore program. Users could access this module through the Musescore application in the Play Store. Users will get a link contains sight-reading material. or access it though MuseScore forum. The table 1 is a list of materials to be provided.

TABLE I. LIST OF MATERIALS TO BE PROVIDED

\begin{tabular}{|c|c|}
\hline Aspect & Lessons \\
\hline \multirow{10}{*}{ Note Value } & Whole notes and whole-note rests \\
\hline & Half notes and half-note rests \\
\hline & Whole notes and half nores \\
\hline & Quarter notes and their rests \\
\hline & Half notes and quarter notes \\
\hline & Whole notes, half notes and quarter notes \\
\hline & Eight notes and eight note rests \\
\hline & Quarter notes and eight notes \\
\hline & Whole notes, half notes, quarter notes and eight notes \\
\hline & Sixteenths \\
\hline \multirow{5}{*}{$\begin{array}{c}\text { Time } \\
\text { Signature }\end{array}$} & $3 / 4$ measure \\
\hline & $2 / 2$ measure \\
\hline & $2 / 4$ measure \\
\hline & $4 / 4$ measure \\
\hline & Syncope \\
\hline
\end{tabular}

Before starting, the user selects the material by placing the pointer in the initial notation of the material. Then press the piano symbol to start sight singing. The display will change to landscape and the user can adjust the track speed. The main screen of the lesson can be seen in figure 1 .

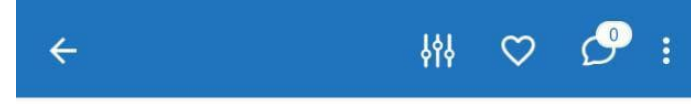

\section{Lessons}

for the different note-values and different kinds of measure Lesson with whole-note and whole-note res The rest is the silence of whole-note.
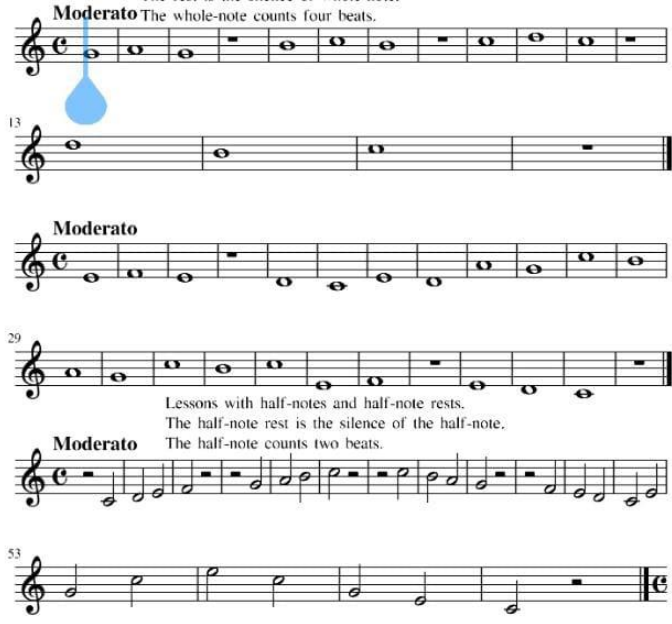

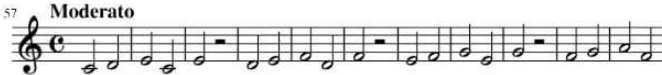
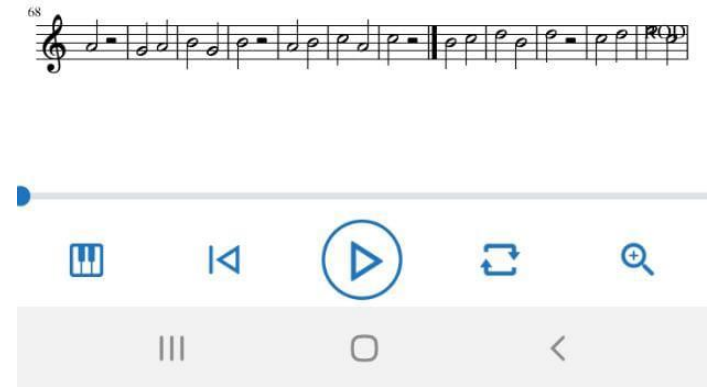

Fig. 1. Main screen of the lesson.

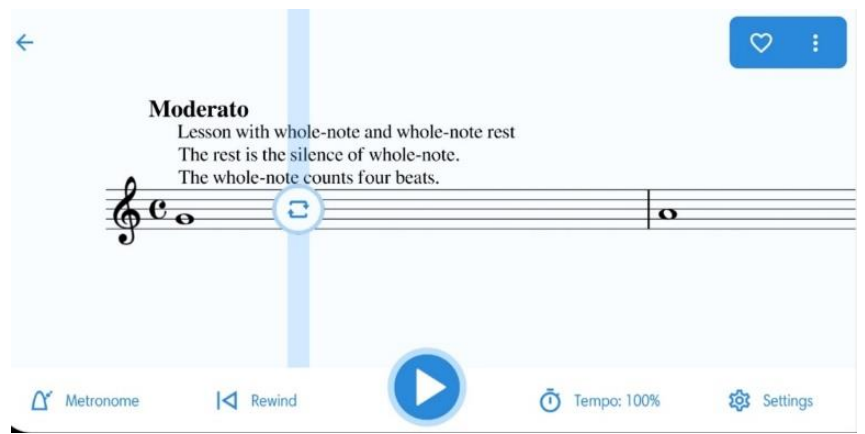

Fig. 2. Lesson line with the play button.

There are several buttons in this screen for settings some aspects in this m-learning (see figure 2):

- Metronome: to adjust the volume of metronome sound

- Rewind button: to start the sight reading from beginning 
- Play: to start the track

- Tempo: to change the speed of track

- Settings: to change the tonality and adjust the volume of sound

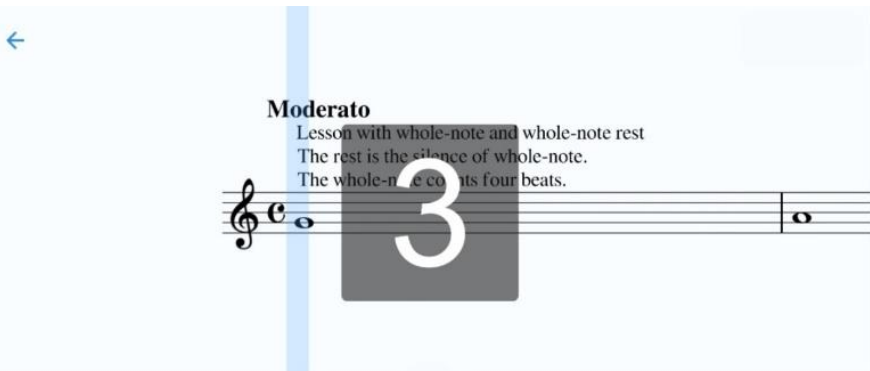

Fig. 3. Countdown before starting the lesson.

The countdown speed will show how fast or slow users should sing the notation (see figure 3 ). To change the speed, users could set it before start the lesson.

\section{CONCLUSION}

M-learning makes it easy for learning inside and outside the classroom because it uses a mobile device. The use of a mlearning offers an alternative in learning and teaching music to increase musical literacy, aural skills and increase selfconfidence. M-learning designed to combine audio and visuals. Multimedia design begins by observing the problems faced, selecting the application that is Musescore and selecting the material to be used, namely Solfège des solfèges by Adolphe Danhauser, determining the material and transcribing the material into Musescore.

\section{REFERENCES}

[1] W. Ho, "Music students' perception of the use of multi-media technology at the graduate level in hong kong higher education," Asia Pacific Educ. Rev. vol. 8, pp. 12-26, 2007.

[2] D. Bray, Teaching music in the secondary school. Oxford: Heinemann, 2000.

[3] I. Yengim, B. Lazarevic, "Mobile Apps for Learning argumentation skills: exploring student perception of dialog games on tablet devices," International Journal of Information and Education Technology, vol. 8, no. 2, pp. 133-138, 2018 .
[4] F. Gértrudix, B. Rivas, and M. Gértrudix, "Analysis of musical learning experiences through the use of digital applications of students in the degree in early childhood education," In INTED2016 Proceedings. 10th International Technology, Education and Development Conference (pp. 3255-3262), 2016

[5] Mahyumi Rantina, Hasmalena, Yosef, Pengembangan lagu berbasis aplikasi musescore dalam pengembangan aspek perkembangan anak usia dini. Jurnal Pendidikan Anak Usia Dini, vol. 4, no 1, 2020, pp. 426-433

[6] S. Román-García, R. Chao-Fernandez, and A. Chao-Fernandez, "ICT in the Music Classroom. Achieving Musical Literacy in the 21st Century," In EDULEARN17 Proceedings (pp. 6205-6213). IATED, 2017.

[7] Y. Chen, "The explorations and implications of EFL class activity design via smartphone applications," International Journal of Information and Education Technology, vol. 7, no. 12, pp. 900-904, 2017.

[8] W.J. Conrad, Music literacy and sight-singing techniques used by elementary and middle school music teachers. Cleveland State University, 2007.

[9] W.C. Ho, "Music students' perception of the use of multi-media technology at the graduate level in Hong Kong higher education," Asia Pacific Education Review, vol. 8, no. 1, pp. 12-26, 2007.

[10] S.C. Ng, A.K. Lui, and W.S. Lo, An interactive mobile application for learning music effectively. In International Conference on ICT in Teaching and Learning (pp. 148-157). Berlin, Heidelberg: Springer.

[11] A. Purwanto, I. Widaningrum, and K.N. Fitri, "Aplikasi musicroid sebagai media pembelajaran seni musik berbasis android," Khazanah Informatika, vol. 5, no. 1, pp. 78-87, 2019.

[12] M. Rogers, "Aural dictation affects high achievement in sight reading, performance and composition skills," Australian Journal of Music Education, no. 1, pp. 34-52, 2013.

[13] T.A. Wolf, “Cognitive model of musical sight-reading,” J Psycholinguist Res., vol. 5, pp. 143-171, 1976.

[14] H.R. Gudmundsdottir, "Advances in music-reading research," Music Education Research, vol. 12, no. 4, pp. 331-338, 2010.

[15] B. Warsita, "Mobile learning sebagai model pembelajaran yang efektif dan inovatif," Jurnal Teknodik, vol. 14, no. 1, pp. 62-73, 2010.

[16] A.T. Korucu, A. Alkan, "Differences between m-learning (mobile learning) and e-learning, basic terminology and usage of m-learning in education," Procedia - Social and Behavioral Sciences, vol. 15, pp 1925-1930, 2011

[17] Samsinar, "Mobile learning dalam pembelajaran," AL-GURFAH Journal of Primary Education, vol. 1, no. 1, 2019.

[18] Musescore, "Why music teachers should use MuseScore," 2020 [Online]. Retrieved from: https://musescore.org/en/why-music-teachersshould-use-musescore.

[19] M. Watson, "MuseScore," Journal of the Musical Arts in Africa, vol. 15, no. $1-2$, pp. 143-147, 2018. 